Molecules 2002, 7, 641-656

molecules

ISSN 1420-3049

http://www.mdpi.org

\title{
2,3-Bifunctionalized Quinoxalines: Synthesis, DNA Interactions and Evaluation of Anticancer, Anti-tuberculosis and Antifungal Activity
}

\author{
Michael J. Waring ${ }^{4}$, Taibi Ben-Hadda ${ }^{1, *}$, Ann T. Kotchevar ${ }^{3}$, Abdelkrim Ramdani ${ }^{1}$, Rachid \\ Touzani ${ }^{1}$, Sghir Elkadiri ${ }^{1}$, Abdelkader Hakkou ${ }^{2}$, Mohamed Bouakka ${ }^{2}$ and Tom Ellis ${ }^{4}$ \\ ${ }^{1}$ Department of Chemistry, Faculty of Sciences, University Mohammed $1^{\text {er }}$, Oujda 60000, Morocco. \\ ${ }^{2}$ Department of Biology, Faculty of Sciences, University Mohammed $1^{\mathrm{er}}$, Oujda 60000, Morocco. \\ ${ }^{3}$ Department of Chemistry and Biochemistry, 1 University Plaza, Long Island University, Brooklyn, \\ NY 11201, USA. \\ ${ }^{4}$ Department of Pharmacology, University of Cambridge, Tennis Court Road, Cambridge, CB2 1QJ, \\ UK.
}

* Author to whom correspondence should be addressed; e- mail: benhadda@ sciences.univoujda.ac.ma, Tel: (+212) 61 753135; Fax : (+212) 56500603.

Received: 13 February 2002; in revised form: 8 August 2002 / Accepted: 10August 2002/Published: 30 August 2002

\begin{abstract}
A variety of 2,3-bifunctionalized quinoxalines (6-14) have been prepared by the condensation of 1,6-disubstituted-hexan-1,3,4,6-tetraones (1-4) with o-phenylenediamine, $(\mathrm{R}, \mathrm{R})$-1,2-diaminocyclohexane and p-nitro-o-phenylenediamine. It is concluded that strong intramolecular $\mathrm{N}-\mathrm{H}----\mathrm{O}$ bonds in the favoured keto-enamine form may be responsible for the minimal biological activities observed in DNA footprinting, antitubercular, anti-fungal and anticancer tests with these hyper $\pi$-conjugated quinoxaline derivatives. However, subtle alteration by addition of a nitro group affecting the charge distribution confers significant improvements in biological effects and binding to DNA.
\end{abstract}

Keywords: Dissymmetric quinoxalines, DNA intercalator, Bayoud, Tuberculosis, Cancer. 


\section{Introduction}

In recent years, polyfunctionalised quinoxalines have been prepared and studied because of their interesting biological activities [1-5] and DNA interactive behaviour [6-8]. Some act as antidiabetic agents [9], anti-HIV agents [10], or NMDA receptor antagonists [11]. Others can be used in $\pi$ conjugated polymer chemistry due to their electron withdrawing properties [12]. In addition, the fluorescence characteristics of 5,8- and 6,7- dimethoxyquinoxaline [13,14] and their potential as fluoroionophores have recently been described [15].

Previously performed ${ }^{1} \mathrm{H}$-, ${ }^{13} \mathrm{C}$ - and ${ }^{15} \mathrm{~N}$-NMR studies have shown that symmetrically substituted quinoxaline ligands 6, 7 and 10 containing phenyl or cyclohexyl rings lead predominantly to a ketoenamine form with $\mathrm{N}-\mathrm{H}---\mathrm{O}$ intramolecular hydrogen bonds [16]. The existence of this preferred tautomeric form was confirmed by X-ray structural studies of 6 and 10. Compounds 6 and 7, containing an extended delocalized $\pi$ system, exhibited fluorescence properties, while $\mathbf{1 0}$ did not. The coexistence of the nine or more tautomeric forms is of particular interest since they present an extended conjugation pathway with a potentially bis-(bidentate) $\mathrm{N}$, O-chelating site (Scheme 1).

Scheme 1: Possible tautomeric forms A-C for symmetric quinoxalines 6-13, and possible tautomeric forms D-I for the dissymmetrically substituted quinoxaline derivative

14.

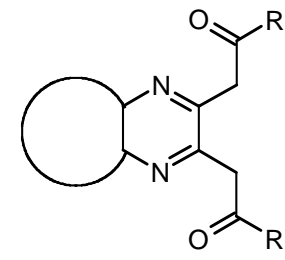

A: keto-imine

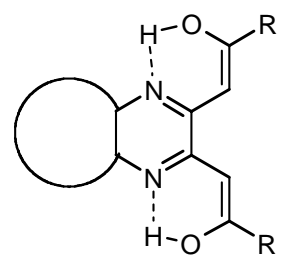

B: enol-imine

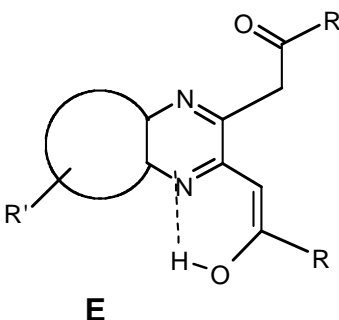

E

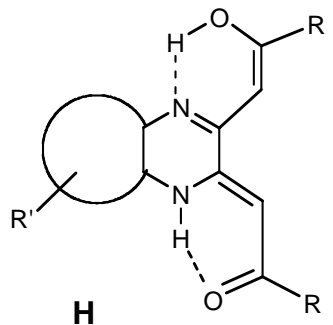

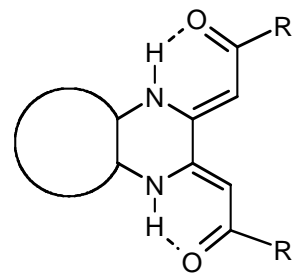

C: keto-enamine<smiles>[R]C(=O)CC1=NC2CCC([R])([R])CCCCC2N2[IH]C=C1C=C2[R]</smiles>

F

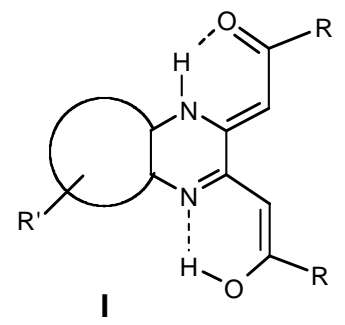


This type of quinoxaline compound bears a strong resemblance to well-characterised drugs that bind to DNA by intercalation [17]. In general, three major aspects of the binding of drugs to DNA may be expected to influence their biological activity: (i) mode of interaction with the double helix, (ii) sequence specificity of binding, and (iii) kinetics of association/dissociation. Compounds 6-14 represent an attractive model for theoretical and experimental study of intercalators and their medical applications because of the variability in their available forms. Moreover, given the current interest in drug targeting to harmful genes through development of molecules that recognize specific DNA sites $[18,19]$, we became interested in the synthesis of 2,3-disubstituted quinoxaline derivatives having an extended conjugation system. As a first step towards studying possible interactions of 6-14 with DNA, we have carried out in vitro anticancer, anti-tubercular and anti-fungal screening, and have examined the DNA interactive properties of the new quinoxalines by DNA footprinting and competition dialysis.

The modulation of the conjugation pathway has been studied by replacing either the external phenyl group with a neo-pentyl group or a propyl group, or the central aromatic portion with a cyclohexyl moiety. The effects of these substitutions on possible anti-tumour activity and interaction with DNA are reported. We also describe our efforts to extend the methodology to the synthesis of pharmacologically important quinoxalines bearing functional groups at positions 2 and 3 of the quinoxaline ring. The development of a short and convergent approach to the synthesis allows us easy access to the new quinoxaline family 6-14.

\section{Results and Discussion}

\section{Chemistry}

Preparation of 2,3-disubstituted quinoxaline compounds in most cases involves the condensation of diketone [12] or diethyl oxalate compounds [11] with $o$-phenylenediamine. One useful route to 2,3difunctionalized quinoxalines is the condensation reaction of diketones with various 1,2-diaminocompounds. Disubstituted hexan-1,3,4,6-tetraones have proven to be versatile reagents employed with substituted hydrazines in the synthesis of bipyrazole ligands [12] and have been used for the synthesis of 2,3-difunctionalized quinoxalines 6-8 [13].

A few synthetic methods are available in the literature but none of them are very convenient. Furthermore, hexan-1,3,4,6-tetraone is not commercially available. Accordingly, we have improved the method described by Finar [12]. Our method is shorter (a 1-day reaction at ambient temperature), the yield is excellent (80-85\%) and the method is delightfully simple as well as convenient compared to other methods in the literature.

The procedure has been used for the direct synthesis of several symmetrically substituted quinoxalines 6-13 and one dissymmetrically substituted quinoxaline 14, all bearing two ketonic arms. The experimental details of the synthesis of compounds $\mathbf{6 , 7}$ and $\mathbf{1 0}$ has been presented elsewhere [16]. For a preparative scale reaction, the commercially available $o$-phenylenediamine was reacted with tetraones 1-4 leading to 6-14, the products shown by TLC after a 30-60 min reflux in ethanol. Filtration 
of compounds 6-14, followed by washing with absolute ethanol to eliminate unreacted starting materials, gave 6-14 in good yield (70-80\%) (Scheme 2).

Scheme 2. Synthesis of quinoxaline derivatives 6-14

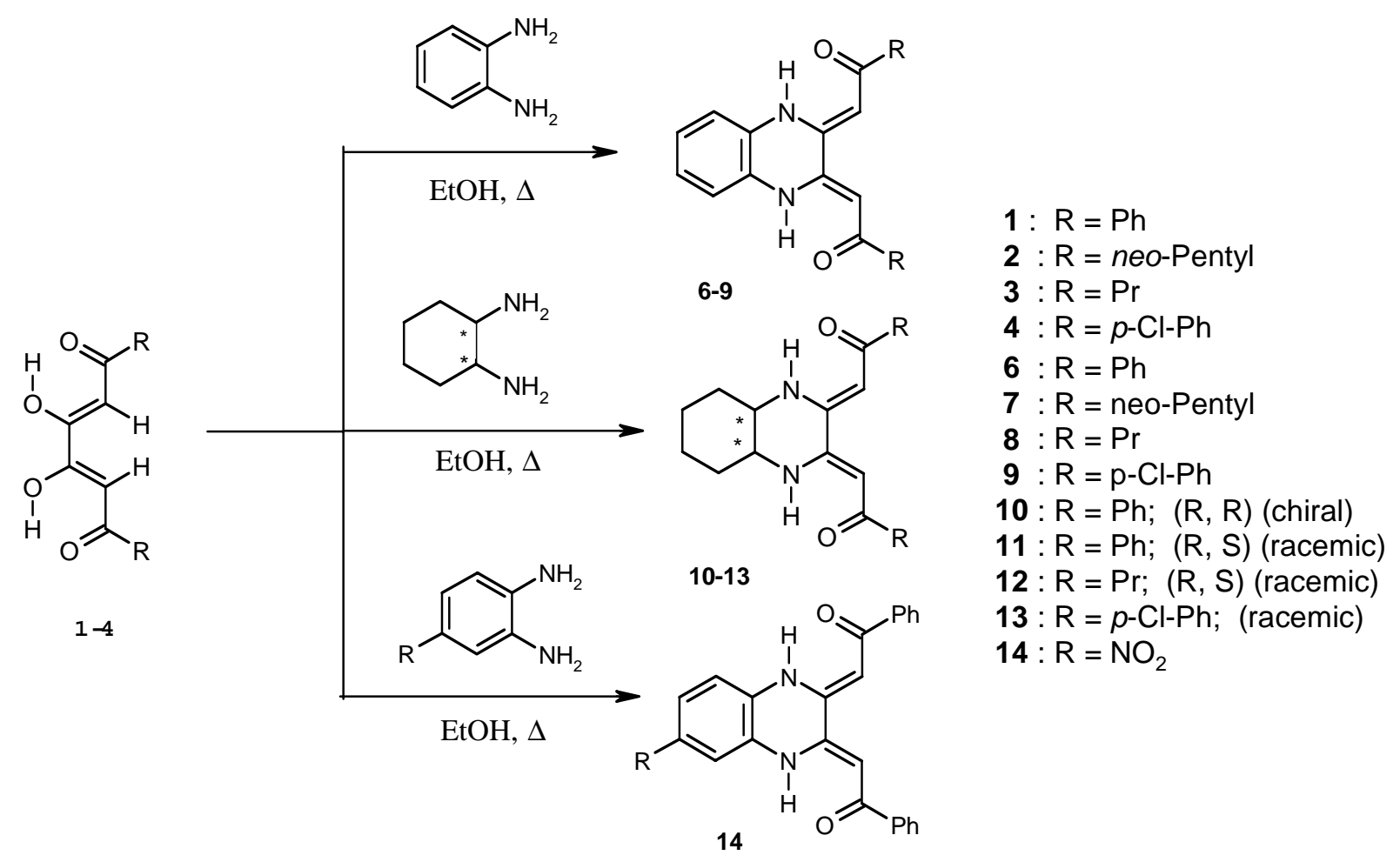

The IR spectrum of the quinoxaline derivative $\mathbf{6}$ shows one broad, weak absorption band around $3440 \mathrm{~cm}^{-1}$ which may be due to a hydrogen bonded $v(\mathrm{OH})$ in the end structure or $v(\mathrm{NH})$ in the enolate/ ammonium form. Both $\mathrm{C}=\mathrm{N}$ imine groups are visible at 1596 and $1563 \mathrm{~cm}^{-1}$ for compound $\mathbf{6}$. These bands correlate with protonated imines, which usually exhibit a variable band in the region 1690-1640 $\mathrm{cm}^{-1}$. This compound also shows two weak $v(C O)$ stretching frequencies at ca. 1735 and $1702 \mathrm{~cm}^{-1}$. From this we can conclude that the symmetric quinoxaline 6 exists in the three principal tautomeric forms A-C as shown in Figure 1. In the ${ }^{1} \mathrm{H}-\mathrm{NMR}$ spectrum of $\mathbf{6}$, the chemical shifts for all four $\mathrm{C}(5)$, $\mathrm{C}(6), \mathrm{C}(7)$ and $\mathrm{C}(8)$ protons coincide at $7.05 \mathrm{ppm}$, with no coupling to any adjacent atoms. The presence of this singlet peak indicates that the keto-enamine form $\mathbf{C}$ is preferred over the other forms $\mathbf{A}$ and $\mathbf{B}$ in the liquid state. A six-membered delocalized ring can be formed by an intramolecular tautomeric shift of the hydroxyl proton to the nitrogen atom, generating the keto-enamine form $\mathbf{C}$. Similar behaviour is equally possible at the second nitrogen centre. This leads to a hyper conjugated quinoxaline derivative that has two identical nitrogen centres since the ligand is highly stabilised by resonance and contains a symmetric charge distribution (Scheme 3). 
Scheme 3. Structure of compound 6 as confirmed by an X-ray study [16]. The structure of compound $\mathbf{1 4}$ as deduced from theoretical limit forms.<smiles>O=C1C=C2C3=CC(c4ccccc4)=C[IH]N3c3ccccc3N2[TlH]O1</smiles>

6

bis- Keto-ene-amine

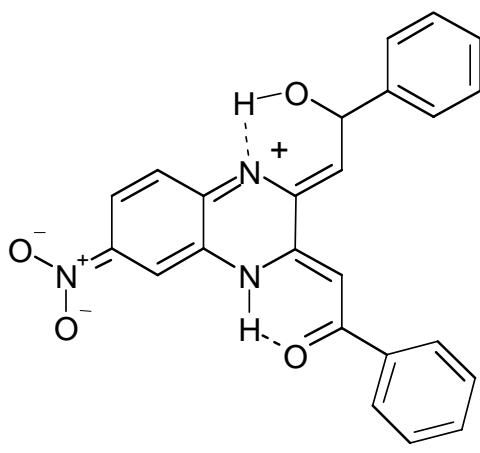

14

hydroxy-ene-imine/ Keto-ene-amine

In contrast to the symmetric quinoxaline derivatives 6-13, the nitro-quinoxaline 14 would have a dissymmetric charge distribution. Therefore, the most probable tautomeric forms for $\mathbf{1 4}$ are $\mathbf{D}$-I. Scheme 1 details the tautomeric cyclization sequence. The initial step of the proposed mechanism involves conjugate tautomerism of the hydroxyl proton to the nitrogen atom. The chemical significance of this migratory proton in cyclisation is apparent not only in the decreased coordination reactivity of these quinoxalines towards transition metals, reflecting electrophilic enhancement by the protonation of the $\mathrm{N}$ centres, but also in the influence on UV/visible spectral behaviour.

These results prompt several pertinent observations: (i) This type of quinoxaline can furnish an interesting model for studying the interaction of quinoxaline antibiotics with DNA because the possible hydrogen-bonding of a proton to the negatively charged centers of DNA is generally favoured; (ii) The $\mathrm{Z} / \mathrm{Z}$ geometric configuration enables us to prepare bimetallic complexes for electronic, photo and magnetic materials; and (iii) Functionalised quinoxalines can easily be prepared from 1,6-disubstituted hexan-1,3,4,6-tetraones and other 1,2-diamino precursors.

\section{Biological Evaluation}

\section{Evaluation of Anti-fungal Activity}

Fusarium oxysporum is a highly pleomorphic organism whose many and varied forms can behave either as saprophytes or parasites in various plants, and among the latter different degrees of virulence can arise [20]. The number of pathogenic forms is estimated at 80. Some of them can infect plants belonging to more than to one family, for example celery and peas. F. oxysporum f.sp albedinis, responsible for the vascular fusariose of the date palm, is a pest that ranks with $F$. oxysporum f.sp cubense (causal agent of the fusariose of the banana tree) high on the list of serious agricultural problems. Antifungal activity was assessed against the albedinis strain. The quinoxaline compounds were dissolved in dimethylsulfoxide with $50 \%$ ethanol, then added at different concentrations into the 
solid culture media. The percentage inhibition of growth was expressed in terms of the ratio of diameter of the treated mycelium to that of the untreated control (Table 1).

Table 1. Antifungal activity of selected quinoxaline compounds 6-9, 11 and 14.

\begin{tabular}{cccccc}
\hline \multirow{2}{*}{ Compound } & Assay & \multicolumn{4}{c}{ Percent growth inhibition (Concentration, mg/L) } \\
\cline { 3 - 5 } & & $(\mathrm{C} 1)$ & $(\mathrm{C} 2)$ & $(\mathrm{C} 3)$ & Assessment \\
\hline $\mathbf{6}$ & Bayoud & $9(20)$ & $7(40)$ & $22(80)$ & Inactive \\
$\mathbf{7}$ & Bayoud & $9(60)$ & $15(120)$ & $15(180)$ & Inactive \\
$\mathbf{8}$ & Bayoud & $17(60)$ & $17(120)$ & $19(180)$ & Inactive \\
$\mathbf{9}$ & Bayoud & $21(60)$ & $32(120)$ & $35(180)$ & Inactive \\
$\mathbf{1 1}$ & Bayoud & $15(34)$ & $31(67)$ & $33(134)$ & Inactive \\
$\mathbf{1 4}$ & Bayoud & $29(18)$ & $31(36)$ & $51(72)$ & Active \\
\hline
\end{tabular}

The most effective inhibitor is $\mathbf{1 4}$, which produces $51 \%$ inhibition of the growth of Fusarium in the presence of $72 \mathrm{mg} / \mathrm{L}$. Molecules 6, 11, and 9 are less effective but produce appreciable growth inhibition at comparable concentrations. Compounds $\mathbf{7}$ and $\mathbf{8}$ only inhibit growth weakly and are considered essentially inactive.

The molecules with the best activity contain a phenyl group on each of the pendant arms of the conjugated chain. The replacement of the two phenyl groups by propyl in compound $\mathbf{8}$ and neo-pentyl in 7 results in a drastic loss of antifungal activity. The loss in activity could be due to the loss of the large, rigid character that the phenyl groups confer on the molecule. Hydrophobic molecules with rigid, planar structures such as aromatic rings, have been shown to have the ability to insert into membranes and induce localized permeability changes leading to leakage out of the membrane [21]. Propyl and neo-pentyl groups, while also hydrophobic and very easily inserted into the membrane, are much less likely to cause disruption of the lipid packing order. On the other hand, the greater activity seen with the nitroquinoxaline (14) versus $\mathbf{6}$ and $\mathbf{1 1}$ cannot be explained by possible cell membrane disturbances as the nitro group is too small to have this type of effect. The enhanced inhibition observed in the presence of $\mathbf{1 4}$ is then more likely due to its interaction with some intracellular target. The presence of a strong electron-withdrawing group must alter the nature of the compound in such a way as to promote binding to the target(s).

\section{Evaluation of Anti-tuberculosis Activity in vitro}

Six compounds $(6-7,9-11,14)$ have been evaluated as anti-tuberculosis agents through the TAACF tuberculosis screening program, but only half of them have been shown to inhibit significantly the growth of Mycobacterium tuberculosis $\mathrm{H}_{37} \mathrm{Rv}$ using the Alamar assay at the first level adopted for in 
vitro screening. The three compounds 7, 9 and $\mathbf{1 4}$ displayed modest in vitro activity (less than 10\%). Not surprisingly, none of these quinoxaline derivatives are currently being examined at the in vivo stage of the tuberculosis screening program. The anti-tuberculosis data are summarised in Table 2.

Table 2. Antitubercular activity of quinoxaline compounds 6-7, 9-11 and 14.

\begin{tabular}{ccccc}
\hline Compound & Assay & MIC $(\mu \mathrm{g} / \mathrm{mL})$ & \% Inhibition & Activity \\
\hline $\mathbf{6}$ & Alamar & $>6.25$ & 0 & - \\
$\mathbf{7}$ & Alamar & $>6.25$ & 7 & - \\
$\mathbf{9}$ & Alamar & $>6.25$ & 9 & - \\
$\mathbf{1 0}$ & Alamar & $>6.25$ & 0 & - \\
$\mathbf{1 1}$ & Alamar & $>6.25$ & 0 & - \\
$\mathbf{1 4}$ & Alamar & $>6.25$ & 7 & - \\
\hline
\end{tabular}

Evaluation of Anti-tumour Activity in vitro

Among a series of eight 2,3-disubstituted quinoxalines bearing a substitution at position 2 of the ring together with various substituents at the $C-6,7$ positions, three compounds (numbers 7, 9 and 10) were selected by the National Cancer Institute for evaluation of their anticancer activity in vitro. The results seemed to confirm that the carboxy or carbethoxy group at positions 2,3 is not helpful, with a few exceptions, in terms of anticancer activity (Table 3).

Table 3. Antitumour activity of selected quinoxalines 7, 9 and 10 in vitro

\begin{tabular}{cccccc}
\hline \multirow{2}{*}{ Compound } & Concentration & Growth percentages \\
\cline { 3 - 6 } & & NCI H460 & MCF7 & SF-268 & Assessment \\
\hline $\mathbf{7}$ & $0.1 \mathrm{mM}$ & 98 & 86 & 105 & Inactive \\
$\mathbf{9}$ & $0.1 \mathrm{mM}$ & 85 & 76 & 95 & Inactive \\
$\mathbf{1 0}$ & $0.1 \mathrm{mM}$ & 89 & 84 & 100 & Inactive \\
\hline
\end{tabular}

The quinoxaline compounds 7, 9 and $\mathbf{1 0}$ are among the least active substances to have been evaluated as antitumour agents in our laboratories. Accordingly, an effort was initiated to establish a pharmacophore hypothesis to delineate the requirements of the active site via a comprehensive program of analogue synthesis and evaluation of the effects of structural modification(s) on anti-tumour activity of 6 . The chosen strategy was formulated by dissecting the two-dimensional parent structure into three regions. Region I is ring A of the quinoxaline, region II, the substituted acyl functional arms at positions 2 and 3 of quinoxaline, and region III, the phenyl group. We then set out to determine the 
resultant in vitro and in vivo effects of chemical alterations in each region. Neither the unsubstituted Aring nor the chiral cyclohexyl B-ring of $\mathbf{1 0}$ endowed anti-tumour activity. The modulating anti-tumour effect(s) of substituents having different electronegative properties, located at the para-phenyl site comprising the A-ring of region I, were ascertained next. A chloro substituent located at the 4-position on the phenyl ring of $\mathbf{9}$ generated the higher anti-tumour activity relative to quinoxalines $\mathbf{7}$ and $\mathbf{1 0}$ in all of the tumour lines tested. However, in general neo-pentyl or other p-phenyl substituents proved to be unhelpful. We postulate that the strong tendency to form an intramolecular $\mathrm{N}-\mathrm{H}----\mathrm{O}$ bond in the predominant (keto-enamine) form is likely to be responsible for the lack of biological activity observed with these hyper $\pi$-conjugated quinoxaline derivatives. If this hypothesis is correct, by modifications of 6 we may be able to modulate the degree of interaction of the compound with DNA.

\section{Investigation of binding to DNA}

Based on the observations of slight spectral shifts in the presence of nucleic acids (data not shown) we used DNase footprinting techniques [22] to gather information about the dynamic equilibria between the different tautomeric forms and DNA. These experiments serve the dual function of establishing whether significant binding to DNA can be detected by protection from nuclease cleavage, and also detecting whether there are any preferred sites at which these new quinoxaline compounds can bind to natural DNA fragments. For this purpose we have used a number of restriction fragments selected to identify possible binding sites; also to investigate cooperativity of ligand binding. PCR technology was employed to make the labelled DNA substrates [23].

The results yield information that can be used for the design of potential drugs to target critical genes by both 'digital' and 'analogue' sequence readout mechanisms [24]. Scheme 4 shows a DNase I footprinting gel obtained with a 117-mer fragment in the presence of quinoxaline derivative 9 (left panel) and compound 14 (right panel) at the concentrations $(\mu \mathrm{M})$ shown at the top of each gel lane. The control tracks labelled ' $\mathrm{Ct}$ ' were not exposed to cleavage by the enzyme. Numbers refer to the nucleotide sequence shown in Scheme 5.

The behaviour of compound 9 is typical of that found for compounds 6, 7, 11 and the purified chiral isomer of $\mathbf{1 1}$. There is no evidence of protection of any DNA sequences against nuclease cutting by any of these compounds even at quite high concentrations. We believe that this is due to the predominance and high stability of the keto-enamine form $\mathbf{C}$ in solution. By contrast, in the case of compound $\mathbf{1 4}$ at moderate to high concentrations footprints can easily be seen. 
Scheme 4. DNase I footprinting

Compound 9

$\begin{array}{lllllllll}\text { Ct } & \mathrm{G}+\mathrm{A} & 0 & 1 & 2.5 & 5 & 10 & 25 & 50\end{array}$

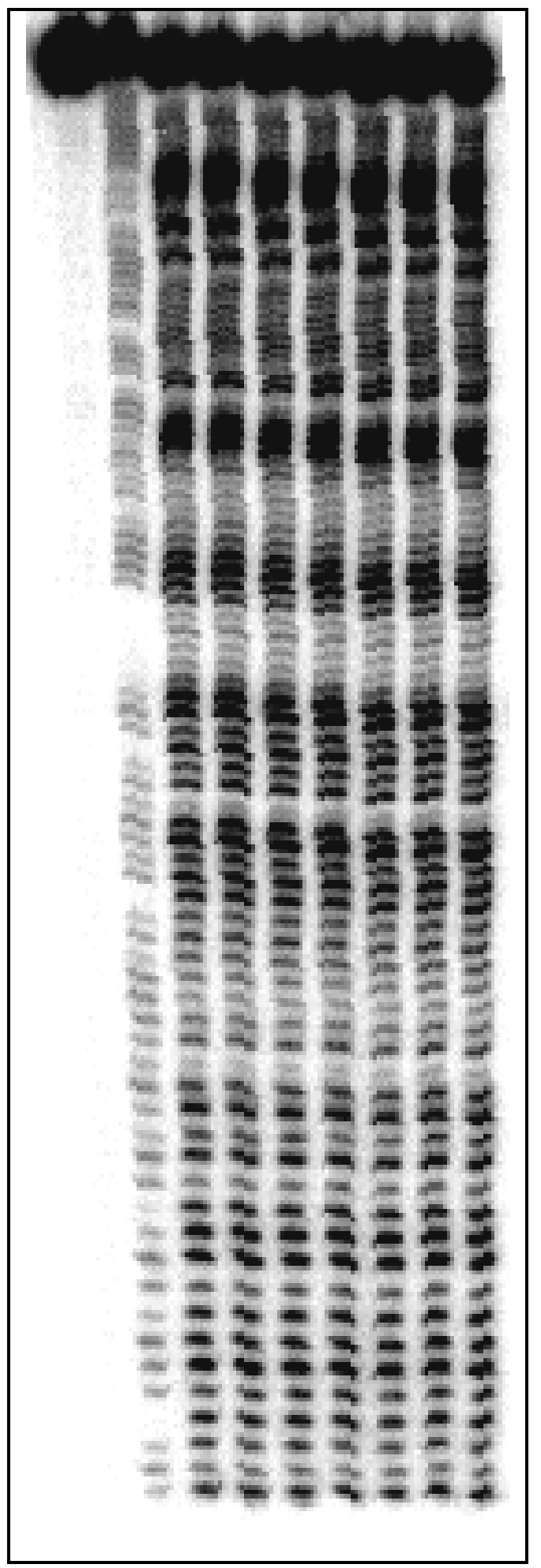

Compound 14

$\begin{array}{lllllllll}\text { Ct } & \mathrm{G}+\mathrm{A} & 0 & 1 & 2.5 & 5 & 10 & 20 & 50\end{array}$

$-110-$

$-100-$

$-80-$

$-70-$

$-60-$

$-50-$

$-40-$

$-30-$

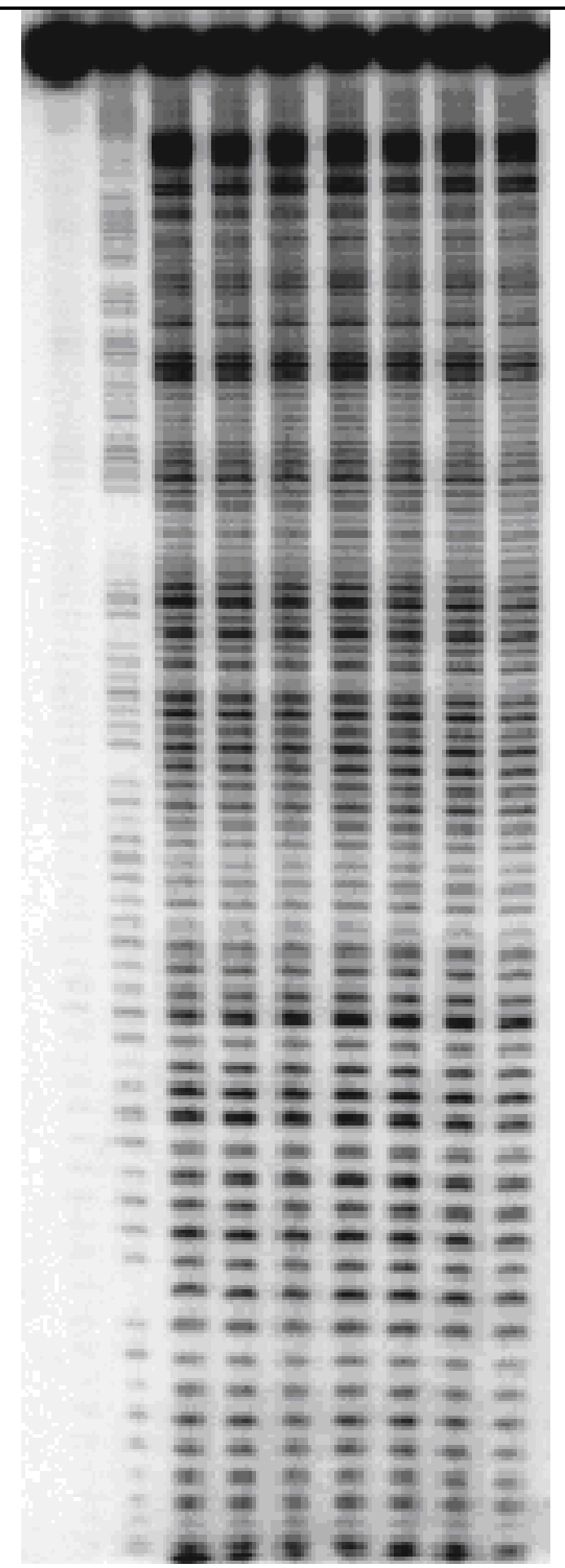




\section{Differential Cleavage Plot}

A differential cleavage plot determined for the nitro-quinoxaline $\mathbf{1 4}$ is illustrated in Scheme 5. It reveals binding sites (regions where the enzyme cutting is inhibited) around positions 95, 89, 78, 68, 60, 53 and probably 18, all of which have at least one GC base pair. Enhanced cleavage, generally seen flanking strong binding sites, is evident at several AT-rich clusters, often oligoA-oligoT tracts, near positions 93, 86, 64, 44 and 26. This type of enhanced cleavage is common with many intercalators[1,24]. We cannot explain the apparently clean enhanced peak in the GC-rich region at position 73, unless it reflects some influence of the small AT tract slightly higher up around 76. Compound 14 appears to be endowed with some type of selectivity for binding to GC-containing sequences (Scheme 5).

Scheme 5: Differential cleavage plot determined for the nitro-quinoxaline derivative 14

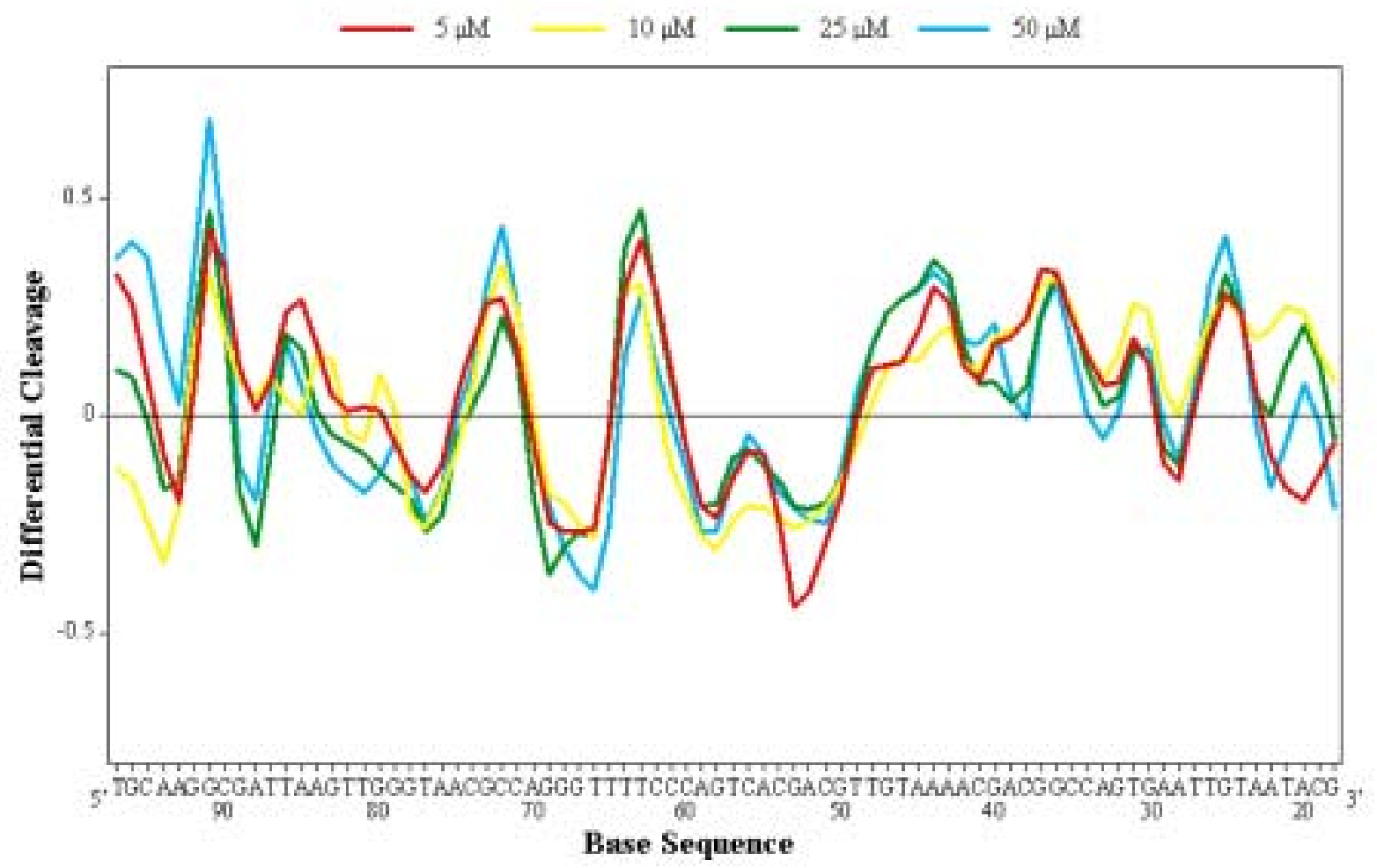

\section{Competition Dialysis}

To check the apparent GC-selectivity of compound $\mathbf{1 4}$ and to look for evidence of structureselective binding to nucleic acids we performed competition dialysis experiments [25,26] with 14, 6, 9 and 11. They confirmed that $\mathbf{1 4}$ has a clear preference for binding to poly(dGdC), though its estimated 
binding constant in $200 \mathrm{mM} \mathrm{NaCl}$ is quite low at $4.3 \times 10^{3} \mathrm{M}^{-1}$. Its 'specificity index' calculated according to Ren and Chaires [26], comparing the binding to poly (dGdC) against all the other 6 polymers we tested, is $65 \%$. The results are graphed in Scheme 6. Our findings with the other quinoxalines are not shown but can be summarised as follows. Compound $\mathbf{6}$ interacts with poly(dGdC) almost as tightly as $\mathbf{1 4}$ but its selectivity, as evidenced by a lack of observable footprinting, is considerably less. Compound 9 binds weakly to poly $(\mathrm{dGdC})$ and poly(dAdT) but shows no detectable interaction with the other nucleic acids. Compound 10 barely interacts with poly $(\mathrm{dGdC})$ but binds weakly to the other nucleic acids at a modest level which suggests little discrimination between types and sequences. In the light of these observations, the lack of footprinting by the latter three compounds is explicable. However, the preference of $\mathbf{1 4}$ vs. $\mathbf{6}$ for binding to GC-rich sequences in natural DNA can not be explained simply by its affinity for the nucleic acids because $\mathbf{6}$ binds about as well to the poly $(\mathrm{dGdC})$ but does not protect GC sequences in the DNA from nuclease cleavage. Further investigation of the effects of electron withdrawing groups on ring A of the quinoxaline is warranted to probe this unique binding seen with compound $\mathbf{1 4}$ (Scheme 6).

Scheme 6 : Competition dialysis representing interaction between 14 and eight nucleic acids

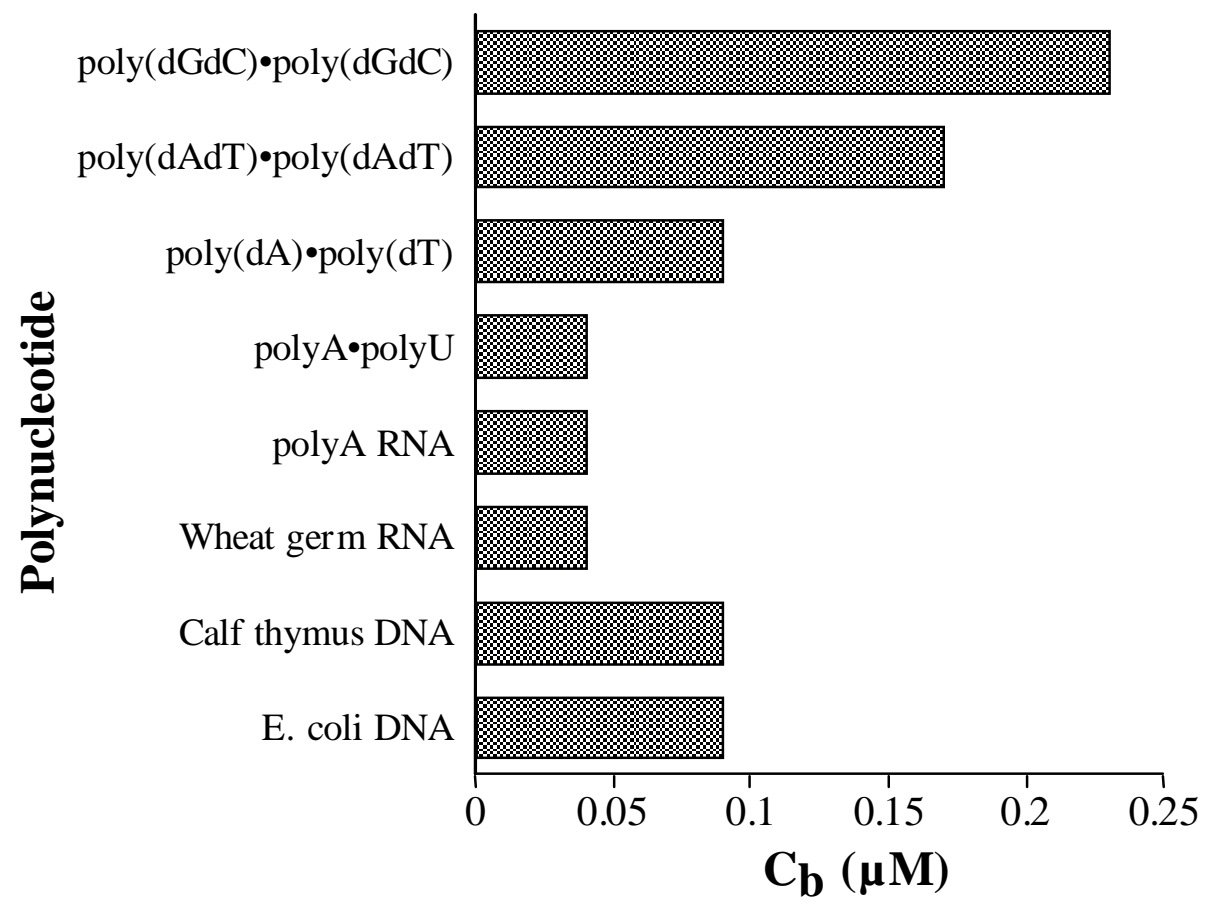

\section{Conclusions}

The 2,3-di-functionalized quinoxalines 6-14 can easily be prepared by condensation of 1,6disubstituted hexan-1,3,4,6-tetraones 1-4 with the appropriate diamines. These compounds typically form the highly stable keto-enamine tautomer. A number of important points emerge concerning their biological properties and interaction with DNA. The weakly positive results we have recorded, while 
not encouraging for purposes of new drug design, confirm that very likely most of these compounds could be used without great risk of toxicity in diverse applications. Based on their fluorescent properties and thermal stability [16], these compounds may be useful as absorption/ fluorescent probes with high quantum yields or as potential chemical precursors to create laser dyes or optic material colorants. The dissymmetric nitroquinoxaline 14, which can evidently recognise specific DNA sequences, has potential for gene targeting which merits investigation of its capacity to inhibit access of activators or repressors to regulatory sites in DNA controlling gene expression.

\section{Acknowledgments}

This work was supported by the Grants from the Ministry of Education of the Kingdom of Morocco (PROTARS No. P1T2/27), the French CNRS (AI N ${ }^{\circ}$ 98/ 160/ SM) and Willaya of Oujda. We would like to thank Advanced Chemistry Development, Inc., Toronto, Canada for the free on-line nomenclature of organic compounds. We are indebted to TAACF and NCI of USA for biological tests. M.J.W. and T.E. were supported by Cancer Research UK.

\section{Experimental}

\section{General}

${ }^{1} \mathrm{H}$ - and ${ }^{13} \mathrm{C}-\mathrm{NMR}$ spectra were recorded on a Bruker DPX 200 (operating at $200.12 \mathrm{MHz}$ for ${ }^{1} \mathrm{H}$, $50.32 \mathrm{MHz}$ for ${ }^{13} \mathrm{C}$ ), a Varian (operating at $60 \mathrm{MHz}$ for ${ }^{1} \mathrm{H}$ ) or on a Bruker AM 300 (operating at $300.13 \mathrm{MHz}$ for ${ }^{1} \mathrm{H}$, at $75.47 \mathrm{MHz}$ for ${ }^{13} \mathrm{C}$ and at $30.42 \mathrm{MHz}$ for ${ }^{15} \mathrm{~N}$ ) spectrometer. Chemical shifts are listed in ppm and are reported relative to tetramethylsilane $\left({ }^{1} \mathrm{H},{ }^{13} \mathrm{C}\right)$, residual solvent peaks being used as internal standard, or relative to nitromethane $\left({ }^{15} \mathrm{~N}\right)$ with external calibration. Complete assignments of the ${ }^{13} \mathrm{C}$ spectra required non-decoupled ${ }^{13} \mathrm{C}$-NMR spectra with selective ${ }^{1} \mathrm{H}$ decoupling. Nondecoupled ${ }^{15} \mathrm{~N}$-NMR spectra were measured in $15 \mathrm{~mm}$ diameter NMR tubes. UV/visible spectra were recorded on a Kontron Uvikon 941 spectrophotometer in dichloromethane solutions. Infrared spectra were obtained on a Brucker IFS28 FTIR spectrometer as $\mathrm{KBr}$ pellets. Elemental analyses were performed by the Centre d'Analyse du CNRS (Solaize, France).

\section{Biological Evaluation}

The antifungal activity of the compounds was measured against Fusarium oxysporum f.sp. albedinis. A stock culture of Fusarium was isolated from a date palm infected by the vascular fusariose. The organism was grown aerobically in liquid Czapek medium of the following composition: $2 \mathrm{~g} / \mathrm{L}$ of $\mathrm{NaNO}_{3}, 1 \mathrm{~g} / \mathrm{L}$ of $\mathrm{K}_{2} \mathrm{HPO}_{4}, 0.5 \mathrm{~g} / \mathrm{L}$ of $\left.\mathrm{MgSO}_{4} \cdot 7 \mathrm{H}_{2} \mathrm{O}\right), 0.01 \mathrm{~g} / \mathrm{L}$ of $\mathrm{FeSO}_{4} \cdot 7 \mathrm{H}_{2} \mathrm{O}$ and $30 \mathrm{~g}$ saccharose/L. The $\mathrm{pH}$ was adjusted to 5.4 with citric acid. All liquid cultures were inoculated into $100 \mathrm{~mL}$ Erlenmeyer flasks with a narrow collar containing $20 \mathrm{~mL}$ of medium at $25^{\circ} \mathrm{C}$, in a water 
bath, with horizontal rotary agitation at $70 \mathrm{rpm}$. The growth was followed by measuring the optical density with a Cecil spectrophotometer at a wavelength of $620 \mathrm{~nm}$ and by counting the organisms on a cell of Malassez under an optical microscope. Cultures on solid medium were seeded in Petri dishes 50 $\mathrm{mm}$ in diameter at $28{ }^{\circ} \mathrm{C}$ in a thermostatically controlled drying oven. The growth was followed by counting colonies for yeast and bacteria and by measuring the diameter of the mycelium for Fusarium.

Anti-tuberculosis activity assays were provided by the Tuberculosis Antimicrobial Acquisition and Coordinating Facility (TAACF) at the Southern Research Institute, Birmingham, AL, USA. Screening was conducted at $6.25 \mu \mathrm{g} / \mathrm{mL}$ against Mycobacterium tuberculosis H37Rv (ATCC 27294) using the Microplate Alamar Blue Assay [27]. In vitro anti-cancer activity was measured by the National Cancer Institute against three cell lines, NCI H460 (Lung), MCF7 (Breast), and SF-268 (CNS). DNase footprinting experiments [22-24], differential cleavage plots [22], and competition dialysis studies $[25,26]$ were conducted as previously described.

\section{Synthesis of Compounds 1-4 and 6-14}

The key intermediates 1-4 were prepared as exemplified by the synthesis of 1,6-bis-neopentylhexan1,3,4,6-tetraone (2) [13]. A suspension of NaOMe was prepared by adding sodium metal ( $23 \mathrm{~g}, 1 \mathrm{~mol})$ in portions to absolute methanol $(500 \mathrm{~mL})$, then a portion of this suspension $(27 \mathrm{~g}, 0.5 \mathrm{~mol})$ was stirred in dry diethyl ether $(300 \mathrm{~mL})$ at $0{ }^{\circ} \mathrm{C}$. A mixture of 4,4-dimetyl-2-pentanone $(57 \mathrm{~g}, 0.5 \mathrm{~mol})$ and diethyl oxalate $(36.5 \mathrm{~g}, 0.25 \mathrm{~mol}$ ) was added dropwise, over $25 \mathrm{~min}$. The mixture was stirred for $12 \mathrm{~h}$ until TLC indicated that all of the 4,4-dimethyl-2-pentanone had been consumed. Compound 2 was precipitated and collected by simple filtration, dissolved in aqueous solution and neutralized with glacia1 acetic acid to yield $42.3 \mathrm{~g}(60 \%)$ of the tile compound as a white-yellow precipitate. $\mathrm{Mp}=96-$ $98{ }^{\circ} \mathrm{C} ;{ }^{1} \mathrm{H}-\mathrm{NMR}\left(\mathrm{CDCl}_{3}\right): \delta 15.0\left(\mathrm{br} \mathrm{s}, \mathrm{w}_{1 / 2}=70 \mathrm{~Hz}, 2 \mathrm{H}, \mathrm{OH}\right), 6.30(\mathrm{~s}, 2 \mathrm{H},=\mathrm{CH}), 2.30\left(\mathrm{~s}, 4 \mathrm{H}, \mathrm{CH}_{2}\right)$, $1.0\left(\mathrm{~s}, 18 \mathrm{H}, \mathrm{CH}_{3}\right) ;{ }^{13} \mathrm{C}-\mathrm{NMR}\left(\mathrm{CDCl}_{3}\right): \delta 201.5(\mathrm{C}=\mathrm{O}), 172.9(=\mathrm{C}-\mathrm{OH}), 100.6(\mathrm{C}-\mathrm{H}), 53.9\left(\mathrm{CH}_{2}{ }^{\mathrm{t}} \mathrm{Bu}\right)$, $32.2\left(\mathrm{CMe}_{3}\right), 29.9\left(\mathrm{CH}_{3}\right)$. IR $\left(\mathrm{cm}^{-1}\right) 1604\left(\mathrm{~s}, v_{\mathrm{C}=\mathrm{O}}\right)$; LRMS (EI): m/z $282\left(\mathrm{C}_{16} \mathrm{H}_{26} \mathrm{O}_{4}, \mathrm{M}^{+}, 100 \%\right)$.

2,3-Bis-[(2-hydroxy-2-phenyl)ethenyl]quinoxaline (6). o-Phenylenediamine (108 $\mathrm{mg}, 1 \mathrm{mmol})$ and tetraketone 1 ( $290 \mathrm{mg}, 1 \mathrm{mmol})$ were stirred in refluxing ethanol $(50 \mathrm{~mL})$ for $30 \mathrm{~min}$. After cooling the mixture to room temperature, the desired compound was crystallized as analytically pure orange crystals from dichloromethane $(293 \mathrm{mg}, 80 \%) . \mathrm{Mp}=218-220{ }^{\circ} \mathrm{C} ;{ }^{1} \mathrm{H}-\mathrm{NMR}\left(\mathrm{CDCl}_{3}\right): \delta 15.0\left(\mathrm{br} \mathrm{s}, \mathrm{w}_{1 / 2}\right.$ $\left.=8.2 \mathrm{~Hz}, 2 \mathrm{H}, \mathrm{H}_{1}\right), 8.0-7.8(\mathrm{~m}, 4 \mathrm{H}, m-\mathrm{H}), 7.6-7 \mathrm{~A}(\mathrm{~m}, 6 \mathrm{H}, o-\mathrm{H}, p-\mathrm{H}), 7.10\left(\mathrm{~m}, 4 \mathrm{H}, \mathrm{H}_{5-7}\right), 6.5(\mathrm{~s}, 2 \mathrm{H}, \mathrm{CH}-$ CO). ${ }^{13} \mathrm{C}-\mathrm{NMR}\left(\mathrm{CDCl}_{3}\right): \delta 188.9(\mathrm{C}=\mathrm{O}), 146.4\left(\mathrm{C}_{2}, \mathrm{C}_{3}\right), 139.3(i-\mathrm{C}), 131.7(p-\mathrm{C}), 128.6(m-\mathrm{C}), 127.2$ $(o-\mathrm{C}), 126.3\left(\mathrm{C}_{4 \mathrm{a}}, \mathrm{C}_{8 \mathrm{a}}, 125.1\left(\mathrm{C}_{6}, \mathrm{C}_{7}\right), 116.9\left(\mathrm{C}_{5}, \mathrm{C}_{8}\right), 87.5(\mathrm{CH}-\mathrm{CO}) ;{ }^{15} \mathrm{~N}-\mathrm{NMR}\left(\mathrm{CDCl}_{3}\right): \delta-250.3(\mathrm{~d}\right.$, ${ }^{1} \mathrm{~J}_{\mathrm{N}-\mathrm{H}}=87 \mathrm{~Hz}$ ); IR $\left(\mathrm{cm}^{-1}\right): 1591$ (s, $v_{\mathrm{C}=\mathrm{O}}$ ). Anal calc. (found) for $\mathrm{C}_{24} \mathrm{H}_{18} \mathrm{~N}_{2} \mathrm{O}_{2}: \mathrm{C} 78.67$ (77.71), H 4.95 (4.80), N 7.65 (7.51).

2,3-Bis-[(2-hydroxy-2-neopentyl)ethenyl]quinoxaline (7). o-Phenylenediamine (108 $\mathrm{mg}, 1 \mathrm{mmol})$ and tetraketone 2 (280 mg, $1 \mathrm{mmol}$ ) were stirred in refluxing ethanol $(50 \mathrm{~mL})$ for $30 \mathrm{~min}$. After cooling, the 
yellow precipitate was filtered off and recrystallized from dichloromethane $(210 \mathrm{mg}, 60 \%)$. $\mathrm{Mp}=220$ $222{ }^{\circ} \mathrm{C} ;{ }^{1} \mathrm{H}-\mathrm{NMR}\left(\mathrm{CDCl}_{3}\right): \delta 14.6\left(\mathrm{br} \mathrm{s}, 2 \mathrm{H}, \mathrm{H}_{1}\right), 7.0\left(\mathrm{~s}, 4 \mathrm{H}, \mathrm{H}_{5-7}\right), 5.6(\mathrm{~s}, 2 \mathrm{H}, \mathrm{CH}-\mathrm{CO}), 2.3(\mathrm{~s}, 4 \mathrm{H}$, $\left.\mathrm{CH}_{2}{ }^{-} \mathrm{Bu}\right), 1.0(\mathrm{~s}, 18 \mathrm{H}, \mathrm{Me}) ;{ }^{13} \mathrm{C} \mathrm{NMR}\left(\mathrm{CDCl}_{3}\right): \delta 198.8(\mathrm{C}=\mathrm{O}), 144.5\left(\mathrm{C}_{2}, \mathrm{C}_{3}\right) .126 .1\left(\mathrm{C}_{4 \mathrm{a}}, \mathrm{C}_{8 \mathrm{a}}\right) 124.5$ $\left(\mathrm{C}_{6}, \mathrm{C}_{7}\right), 116.5\left(\mathrm{C}_{5}, \mathrm{C}_{8}\right), 92.0(\mathrm{CH}-\mathrm{CO}), 56.1\left(\mathrm{CH}_{2}{ }^{\mathrm{t}} \mathrm{Bu}\right), 31.9\left[\mathrm{CH}_{2}-\mathrm{C}\left(\mathrm{CH}_{3}\right)\right], 30.1\left[\mathrm{CH}_{2}-\mathrm{C}\left(\mathrm{CH}_{3}\right)\right]$;

${ }^{15} \mathrm{~N}-\mathrm{NMR}\left(\mathrm{CDCl}_{3}\right): \delta-254.3\left(\mathrm{~d},{ }^{1} \mathrm{~J}_{\mathrm{N}-\mathrm{H}}=87 \mathrm{~Hz}\right)$; IR $\left(\mathrm{KBr}, \mathrm{cm}^{-1}\right)$ : $1595\left(\mathrm{~s}, \mathrm{v}_{\mathrm{C}=\mathrm{O}}\right)$; Anal. calc. (found) for $\mathrm{C}_{22} \mathrm{H}_{30} \mathrm{~N}_{2} \mathrm{O}_{2} \cdot \mathrm{H}_{2} \mathrm{O}: \mathrm{C} 71.13$ (71.87), H 8.41 (8.37), N 7.54 (7.63).

2,3-Bis-[(2-hydroxy-2-propyl)ethenyl]quinoxaline (8). o-Phenylenediamine $(108 \mathrm{mg}, 1 \mathrm{mmol})$ and tetraketone $3(226 \mathrm{mg}, 1 \mathrm{mmol})$ were stirred in refluxing ethanol $(50 \mathrm{~mL})$ for $60 \mathrm{~min}$. After cooling, the precipitate was filtered off as a brown powder $(238 \mathrm{mg}, 80 \%)$. Mp $=115-117{ }^{\circ} \mathrm{C} ;{ }^{1} \mathrm{H}-\mathrm{NMR}\left(\mathrm{CDCl}_{3}, 60\right.$ MHz): $\delta 14.15$ (s, 2H, -OH), 7.00 (s, 4H, aromatic $\left.\mathrm{CH}, \mathrm{H}_{5}, 8\right), 5.68$ (s, $\left.2 \mathrm{H}, \mathrm{CH}-\mathrm{CO}\right), 2.40$ (t, 4H, $\underline{\mathrm{CH}}_{2}-$ $\left.\mathrm{CH}_{2} \mathrm{CH}_{3},{ }^{1} \mathrm{~J}_{\mathrm{H}-\mathrm{H}}=15 \mathrm{~Hz}\right), 1.60\left(\mathrm{~m}, 4 \mathrm{H}, \mathrm{CH}_{2}-\underline{\mathrm{CH}}_{2} \mathrm{CH}_{3},{ }^{1} \mathrm{~J}_{\mathrm{H}-\mathrm{H}}=8 \mathrm{~Hz}\right), 0.95\left(\mathrm{t}, 6 \mathrm{H}, \mathrm{CH}_{2}-\mathrm{CH}_{2} \underline{\mathrm{CH}}_{3},{ }^{1} \mathrm{~J}_{\mathrm{H}-\mathrm{H}}=\right.$ $4.3 \mathrm{~Hz}$ ); IR ( $\left.\mathrm{cm}^{-1}\right): 3450\left(\mathrm{~m}, v_{\mathrm{OH}}\right.$ ); Anal. calc. (found) for $\mathrm{C}_{18} \mathrm{H}_{22} \mathrm{~N}_{2} \mathrm{O}_{2}$ : C 72.44 (72.60), H 7.37 (7.48), N 9.39 (9.55).

2,3-Bis-[2-hydroxy-2-(4-chlorophenyl)ethenyl]quinoxaline (9). o-Phenylenediamine (108 $\mathrm{mg}, 1 \mathrm{mmol}$ ) and tetraketone 4 (362 mg, $1 \mathrm{mmol})$ were stirred in refluxing ethanol $(50 \mathrm{~mL})$ for $60 \mathrm{~min}$. After cooling, the yellow precipitate was filtered off $(325 \mathrm{mg}, 75 \%)$. Mp $=230-232{ }^{\circ} \mathrm{C} ;{ }^{1} \mathrm{H}-\mathrm{NMR}\left(\mathrm{CDCl}_{3}, 60\right.$ MHz): $\delta$ 7.55-8.25 (m, 10H, aromatic CH), $7.15\left(\mathrm{~s}, 4 \mathrm{H}, \mathrm{H}_{5-8}\right), 6.5$ (s, 2H, CH-CO); IR $\left(\mathrm{cm}^{-1}\right): 3500$ (f, $\left.v_{\mathrm{OH}}\right) ; \mathrm{MS}$ for $\mathrm{C}_{24} \mathrm{H}_{16} \mathrm{~N}_{2} \mathrm{O}_{2} \mathrm{Cl}_{2}: \mathrm{m} / \mathrm{z}$ calc. $=435.0667$, found 435.0666 .

(4aR,8aR)-2,3-Bis-[(2-hydroxy-2-phenyl)ethenyl]decahydro-quinoxaline $\quad(\mathbf{1 0}) . \quad(\mathrm{R}, \mathrm{R})-1,2$-diaminocyclohexane $(114 \mathrm{mg}, 1 \mathrm{mmol})$ and the tetraketone $1(280 \mathrm{mg}, 1 \mathrm{mmol})$ were stirred in refluxing ethanol $(50 \mathrm{ml})$ for $30 \mathrm{~min}$. After cooling to room temperature, the yellow precipitate was filtered and recrystallized from dichloromethane $(260 \mathrm{mg}, 70 \%) . \mathrm{Mp}=254-256{ }^{\circ} \mathrm{C} ;{ }^{1} \mathrm{H}-\mathrm{NMR}\left(\mathrm{CDCl}_{3}\right): \delta 11.30(\mathrm{br}$ s, 2H, $\left.\mathrm{H}_{1}\right) .8 .0-7.8(\mathrm{~m}, 4 \mathrm{H}, m-\mathrm{H}), 7.6-7.4(\mathrm{~m}, 6 \mathrm{H}, o-\mathrm{H}, p-\mathrm{H}), 6.3(\mathrm{~s}, 2 \mathrm{H}, \mathrm{CH}-\mathrm{CO}) .3 .20\left(\mathrm{~m}, 2 \mathrm{H}, \mathrm{H}_{4 \mathrm{a}}, 8 \mathrm{a}\right)$, $1.8\left(\mathrm{~m}, 4 \mathrm{H}, \mathrm{H}_{5,8}\right), 1.2\left(\mathrm{~m}, 4 \mathrm{H}, \mathrm{H}_{6,7}\right) ;{ }^{13} \mathrm{C}-\mathrm{NMR}\left(\mathrm{CDCl}_{3}\right): \delta 190.2(\mathrm{C}=\mathrm{O}), 153.2\left(\mathrm{C}_{2}, \mathrm{C}_{3}\right), 140.0(\mathrm{i}-\mathrm{C})$, $131.4(p-\mathrm{C}), 128.5(m-\mathrm{C}), 127.1(o-\mathrm{C}), 89.0(\mathrm{CH}-\mathrm{CO}), 54.7\left(\mathrm{C}_{4 \mathrm{a}}, \mathrm{C}_{8 \mathrm{a}}\right), 29.7\left(\mathrm{C}_{5}, \mathrm{C}_{8}\right), 24.0\left(\mathrm{C}_{6}, \mathrm{C}_{7}\right)$; ${ }^{15} \mathrm{~N}-\mathrm{NMR}\left(\mathrm{CDCl}_{3}\right): \delta-270.7\left(\mathrm{~d},{ }^{1} \mathrm{~J}_{\mathrm{N}-\mathrm{H}}=94 \mathrm{~Hz}\right)$; IR $\left(\mathrm{cm}^{-1}\right): 1600\left(\mathrm{~s}, \mathrm{v}_{\mathrm{C}=\mathrm{O}}\right)$; Anal. calc. (found) for $\mathrm{C}_{24} \mathrm{H}_{24} \mathrm{~N}_{2} \mathrm{O}_{2} . \mathrm{H}_{2} \mathrm{O}: \mathrm{C} 73.82$ (73.07), H 6.65 (6.08), N 7.17 (6.54).

( \pm )-(4aR,8aS)-2,3-bis-[(2-hydroxy-2-phenyl)ethenyl]decahydro-quinoxaline (11). ( \pm )-1,2-diaminocyclohexane $(342 \mathrm{mg}, 3 \mathrm{mmol})$ and the tetraketone $1(900 \mathrm{mg}, 3 \mathrm{mmol})$ were stirred in refluxing ethanol $(50 \mathrm{~mL})$ for $60 \mathrm{~min}$. After cooling to room temperature, the yellow precipitate was filtered without further purification $(780 \mathrm{mg}, 70 \%)$. $\mathrm{Mp}>230{ }^{\circ} \mathrm{C} ;{ }^{1} \mathrm{H}-\mathrm{NMR}\left(\mathrm{CDCl}_{3}\right)$ : $\delta 11.30$ (br s, $\left.2 \mathrm{H}, \mathrm{H}_{1}\right)$. 8.0-7.8 (m, $4 \mathrm{H}, m-\mathrm{H}), 7.6-7.4(\mathrm{~m}, 6 \mathrm{H}, o-\mathrm{H}, p-\mathrm{H}), 6.3(\mathrm{~s}, 2 \mathrm{H}, \mathrm{CH}-\mathrm{CO}), 3.20\left(\mathrm{~m}, 2 \mathrm{H}, \mathrm{H}_{4 \mathrm{a}}, 8 \mathrm{a}\right), 1.8(\mathrm{~m}, 4 \mathrm{H}$, $\left.\mathrm{H}_{5,8}\right), 1.20\left(\mathrm{~m}, 4 \mathrm{H}, \mathrm{H}_{6,7}\right) ; \mathrm{IR}\left(\mathrm{cm}^{-1}\right): 1600\left(\mathrm{~s}, v_{\mathrm{C}=0}\right)$. 


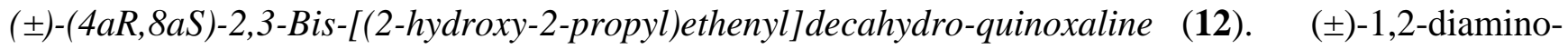
cyclohexane $(342 \mathrm{mg}, 3 \mathrm{mmol})$ and the tetraketone $3(700 \mathrm{mg}, 3 \mathrm{mmol})$ were stirred in refluxing ethanol $(50 \mathrm{ml})$ for $60 \mathrm{~min}$. After cooling to room temperature, the white precipitate was filtered off without further purification $(730 \mathrm{mg}, 80 \%) . \mathrm{Mp}=182-184{ }^{\circ} \mathrm{C} ;{ }^{1} \mathrm{H}-\mathrm{NMR}\left(\mathrm{CDCl}_{3}\right): \delta 11.15(\mathrm{br} \mathrm{s}, 2 \mathrm{H}$, $\mathrm{OH}), 6.75(\mathrm{~s}, 2 \mathrm{H}, \mathrm{CH}-\mathrm{CO}), 3.25\left(\mathrm{t}, 4 \mathrm{H}, \underline{\mathrm{CH}}_{2}-\mathrm{CH}_{2} \mathrm{CH}_{3},{ }^{1} \mathrm{~J}_{\mathrm{H}-\mathrm{H}}=14.8 \mathrm{~Hz}\right), 2.55-2.15\left(\mathrm{~m}, 4 \mathrm{H}, \mathrm{CH}_{2}-\right.$ $\left.\underline{\mathrm{CH}}_{2} \mathrm{CH}_{3},{ }^{1} \mathrm{~J}_{\mathrm{H}-\mathrm{H}}=7.5 \mathrm{~Hz}\right), 0.95\left(\mathrm{t}, 6 \mathrm{H}, \mathrm{CH}_{2}-\mathrm{CH}_{2} \underline{\mathrm{CH}}_{3},{ }^{1} \mathrm{~J}_{\mathrm{H}-\mathrm{H}}=7.3 \mathrm{~Hz}\right), 1.25-1.85$ (m, $10 \mathrm{H}, \mathrm{C}-\mathrm{H}, \mathrm{H}_{4 \mathrm{a}-8 \mathrm{a}}$ ); IR $\left(\mathrm{cm}^{-1}\right): 1700\left(\mathrm{~s}, v_{\mathrm{C}=\mathrm{O}}\right)$.

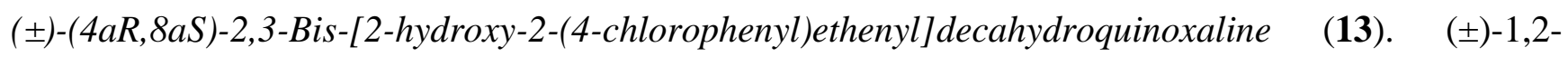
diaminocyclohexane $(342 \mathrm{mg}, 3 \mathrm{mmol})$ and the tetraketone $4(1100 \mathrm{mg}, 3 \mathrm{mmol})$ were stirred in refluxing ethanol $(50 \mathrm{~mL})$ for $60 \mathrm{~min}$. After cooling to room temperature, the yellow precipitate was filtered without further purification $(1060 \mathrm{mg}, 80 \%) . \mathrm{Mp}=176-178{ }^{\circ} \mathrm{C} ;{ }^{1} \mathrm{H}-\mathrm{NMR}\left(\mathrm{CDCl}_{3}\right): \delta 11.35$ (br

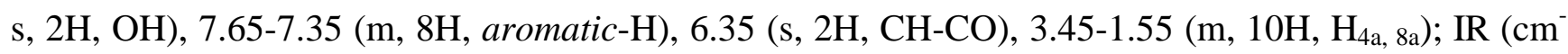
$\left.{ }^{1}\right): 1600\left(\mathrm{~s}, \mathrm{v}_{\mathrm{C}=\mathrm{O}}\right)$.

2,3-bis-[(2-hydroxy-2-phenyl)ethenyl]-6-nitro-quinoxaline (14). p-Nitro-o-phenylenediamine (459 mg, $3 \mathrm{mmol}$ ) and the tetraketone 1 (900 mg, $3 \mathrm{mmol}$ ) were stirred in refluxing ethanol $(50 \mathrm{~mL})$ for $60 \mathrm{~min}$. After cooling to room temperature, the yellow precipitate was filtered off without further purification $(850 \mathrm{mg}, 70 \%) . \mathrm{Mp}=178-180{ }^{\circ} \mathrm{C} ;{ }^{1} \mathrm{H}-\mathrm{NMR}\left(\mathrm{CDCl}_{3}, 60 \mathrm{MHz}\right): \delta 7.55-8.45(\mathrm{~m}, 10 \mathrm{H}$, aromatic $-\mathrm{H})$, 7.35 (m, 3H, CH, $\mathrm{H}_{5,7,8}$ ), 7.05 (s, 2H, CH-CO). IR ( KBr, $\left.\mathrm{cm}^{-1}\right): 1603$ (s, $\mathrm{v}_{\mathrm{C}=\mathrm{O}}$ ).

\section{References}

1. Bailly, C.; Waring, M.J. Biochem. J., 1998, 330, 81-87.

2. Addess, K.J.; Feigon, J. Nucleic Acids Res., 1994, 22, 5484-5491.

3. Branka, J.E.; Vallette, G.; Jarry, A.; Laboisse, C.L. Biochem. J., 1997, 323, 521-524.

4. Balzarini, J.; Karisson, A.; Meichsner, C.; Riess, A.Ps.G.; De Clercq, E.; Kleim, J.P. J. Virol. 1994, 68, 7986-7992.

5. Stilwell, W.G.; Turesky, R.J.; Sinha, R.; Skiper, P.L.; Tannenbaum S.R. Cancer Lett. 1999, 143, 145-148.

6. Nallas, G.N.A.; Brewer, K.J. Inorg. Chim. Acta, 1996, 253, 7-13.

7. Milkevitch, M.; Brauns, E.; Brewer, K.J. Inorg. Chem. 1996, 35, 1737.

8. Molnar, S.M.; Nallas, G.; Bridgewater, J.S.; Brewer, K.J. J. Am. Chem. Soc. 1994, 116, 5206-5210.

9. El-Bendary, E.R.; El-Ashmawy, M.B.; Barghash, A.M.; Shehata, I.A. and El-Kerdawy, M.M.; Boll. Chim. Farm. 1996, 135, 617-620.

10. Keeble, J.; Al-Swayeh, O. A. and Moore, P. K.; Br. J. Pharmacol., 2001, 133, 1023-1028.

11. Lin, S.-K.; Molecules, 1996, 1, 37-40.

12. Finar, I.L. J. Chem. Soc. 1955, 1205-1209. 
13. Wolfe, J.F.; Portlock, D.E.; Feuerbach, D.J. J. Org. Chem. 1974, 39, 2006-2009.

14. Kaiser, E.M.; Petty, J.D. J. Organomet. Chem. 1976, 108, 139-143.

15. Lee, B.L.; Yamamoto, T.; Macromolecules, 1999, 32, 1375-1382.

16. Touzani, R. Ben-Hadda, T.; Elkadiri, S.; Ramdani, A.; Maury, O.; Le Bozec, H.; Toupet, L.; Dixneuf, P. H. New J. Chem. 2001, 25, 391-395.

17. Gale, E.F.; Cundliffe, E.; Reynolds, P.E.; Richmond, M.H.; Waring, M.J. The Molecular Basis of Antibiotic Action, $2^{\text {nd }}$ ed.; John Wiley \& Sons: London, 1981, pp 258-401.

18. Waring, M.J.; Ponder, B.A.J. The Search for New Anticancer Drugs; Kluwer: Dordrecht, 1992.

19. Waring, M.J., In Molecular Aspects of Anticancer Drug-DNA Interactions, Vol. 1 (S. Neidle and M.J. Waring, Eds.); Macmillan: London, 1993, pp 213-242.

20. Gordon, T. R.; Martyn, R. D.; Annu. Rev. Phytopathol. 1997. 35, 111- 128.

21. Kotchevar, A.T., Ghosh, P., Uckun, F.M. J. Phys. Chem. B 1998, 102, 10925-10930.

22. Bailly, C.; Crow, S.; Minnock, A.; Waring, M.J. J. Mol. Biol. 1999, 291, 561-573.

23. Bailly, C. ; Waring, M.J. Nucleic Acids Res. 1998, 26, 4309-4314.

24. Bailly, C.; Mollegaard, N.E.; Nielsen P.E.; Waring, M.J. EMBO J. 1995, 14, 2121-2131.

25. Ren, J.; Chaires, J.B. Biochemistry, 1999, 38, 16067-16075.

26. Ren, J.; Chaires, J.B. Methods in Enzymol. 2001, 340, 99-108.

27. Collins, L.; Franzblau, S.G. Antimicrob. Agents Chemother. 1997, 41, 1004-1009.

Sample Availability: Not Available.

(C) 2002 by MDPI (http://www.mdpi.org). Reproduction is permitted for non commercial purposes. 